\title{
Early Life History of Coreoperca herzi in Han River, Korea
}

\begin{tabular}{|l|} 
W) \\
upeck for \\
updates
\end{tabular}

Received: February 3, 2020

Revised: February 10, 2020

Accepted: February 25, 2020

${ }^{+}$Corresponding author Kyeong-Ho Han

Dept. of Aquaculture, Chonnam National University, Yeosu 59626, Korea.

Tel: +82-61-659-7163

Fax: +82-61-659-7169

E-mail:aqua05@jnu.ac.kr

Copyright $\odot 2020$ The Korean Society of Developmental Biology.

This is an Open Access article distributed under the terms of the Creative Commons Attribution Non-Commercial License (http://creativecommons.org/licenses/ by-nc/4.0/) which permits unrestricted non-commercial use, distribution, and reproduction in any medium, provided the original work is properly cited.

ORCID

Jae-Min Park

https://orcid.org/0000-0001-6398-1748 Hyung-Bae Jeon

https://orcid.org/0000-0002-0819-5004

Ho Young Suk

https://orcid.org/0000-0002-5338-3362

Seong-Jang Cho

https://orcid.org/0000-0002-7347-1706

Kyeong-Ho Han

https://orcid.org/0000-0001-5918-3196

Conflict of interests

The authors declare no potential conflict of interest.

Acknowledgements

Not applicable.

Authors' contributions Conceptualization: Park JM. Data curation: Jeon HB, Cho SJ. Formal analysis: Jeon $\mathrm{HB}$.

Methodology: Han KH, Suk HY.

Software: Park JM

\author{
Jae-Min Park ${ }^{1}$, Hyung-Bae Jeon ${ }^{2}$, Ho Young Suk ${ }^{3}$, Seong-Jang $\mathrm{Cho}^{4}$, and \\ ${ }^{\dagger}$ Kyeong-Ho $\operatorname{Han}^{5}$ \\ ${ }^{1}$ Gyeongsangbuk-Do Native Fish Business Center, Uiseong 37366, Korea \\ ${ }^{2}$ Dept. of Biology, Concordia University, Montreal H4B 1R6, Canada \\ ${ }^{3}$ Dept. of Life Sciences, Yeungnam University, Gyeongsan 38541, Korea \\ ${ }^{4}$ Boryeong Freshwater Eco Center, Boryeong 33416, Korea \\ ${ }^{5}$ Dept. of Aquaculture, Chonnam National University, Yeosu 59626, Korea
}

\section{Abstract}

This study aimed to investigate early life of Coreoperca herzi living in Han River and compare morphological differences between different groups during the development in order to provide basic data for relevant taxonomic research. On average, one female individual spawned 541 to 861 eggs (average 701) at once. After 259 hours, the tail broke out of the egg membrane and hatching began. Immediately after hatching, the larvae were average $7.81 \pm 0.10 \mathrm{~mm}(n=5)$ in total length. 60 days the juvenile was average $35.9 \pm 1.30 \mathrm{~mm}(\mathrm{n}=5)$ in total length. The white spots spread to the rest of the body, rending the same pattern as that on the body of their broodstock fish.

Keywords: Coreoperca herzi, Early life history, Egg, Juvenile, Larvae

\section{INTRODUCTION}

Coreoperca herzi is a species that belongs to the genus Coreoperca in the family Centropomidae of order Perciformes. There are two species of C. kawamebari including C. herzi found in the Korean Penninsula (Han et al., 1998; Kim et al., 2005).

Korea presents clear geographical that is divided into west Korea subdistrict comprising Taedong River, Han River, Geum River, Dongjin River, etc. flowing to the Western sea; Korea subdistrict comprising the Rivers flowing into east-north Korea subdistrict such as Yeongsan River, Seomjin River, and Nakdong River and those flowing into the mid-South such as Taehwa River, Hyeongsan River, Osip, and Jusu streams; and north-East-Korea River comprising Rivers flowing into the northern East sea such as Namdaecheon and Daebongcheon in Gangneung and Bukdaecheon, Eorangcheon, and Duman River in North Korea (Kim, 1997).

Freshwater fish vary greatly in composition according to the water stream and new species are being reported even now. Related research reported Tanakia latimarginata, a new speices that is genetically and morphologically different from T. limbata which inhabits Nakdong. Another example is Liobagrus mediadiposalis, which is found in Seomjin River and has been reported as L. somjinesis due to its black tip of the caudal that is darker than those found in other water systems and present different genetics (Park \& Kim, 2010). Inhabiting Seomjin River and Nakdong River, Coreoleuciscus splendidus has been reported as $C$. aeruginos as a result of difference in fin pattern and genetic analysis result from those in 
Validation: Han KH, Suk HY. Investigation: Cho SJ.

Writing - original draft: Park JM, Jeon HB. Writing - review \& editing: Park JM, Jeon HB. other water systems (Song \& Bang, 2015).

C. herzi is reportedly found in Wangpi stream and other streams that flow into South-West or East sea and also in the north Yeongdong region to which it has immigrated (Jeon, 1980). Recently, the group found in Han River has white spots on the body, which is not presented in groups inhabiting Geum River, Mangyeong River, Seomjin River, and Nakdong River (Jeon, 2005). Later, a molecular phylogenetic study on Korean C. herzi found two species living in Korea (Kim, 2005), although taxonomic research is yet to be conducted.

Investigation into early life of fish provides much information from characteristics of the eggs to intrinsic traits and the developmental process including development in egg, larva, juvenile, and immature fish periods. In other words, research on reproductive ecology and early life of fish helps gain understanding of the species as well as various types of taxonomic and ecological knowledge (Song \& Choi, 2000). The early life of C. herzi was invesetigated by Han et al. (1998), focusing on the groups found in Gyeongho River and Deokcheon River, tributaries of Nakdong River, but further research was needed to see if there is any difference during the early development in the group inhabiting Han River, which presented different colors. Therefore, this study aimed to investigate early life of $C$. herzi living in Han River and compare morpholocial differences between different groups during the development in order to provide basic data for relevant taxonomic research.

\section{MATERIALS AND METHODS}

\section{Broodstock}

For this study, 50 male and female individuals of broodstock fish were captured by using a fish trap in Han River, located in Danyang-gun, Chungcheongbuk-do, in March 2017. The fish was then moved to a round tank in the lab and bred by using running water culture. The broodstock was $10.0-14.5 \mathrm{~cm}$ (average $12.2 \pm 3.18, \mathrm{n}=20$ ) in the whole length. For feed, live juvenile fish such as carp and koi carp were supplied once a day. And to induce natural spawning and provide a shelter, a polyvinyl chloride (PVC) pipe was placed inside the tank.

\section{Egg Development and larva formation}

Of the fertilized eggs spawned on the PVC pipe, 100 fertilized eggs were collected to observe the fertilization and hatching rates and looked after until hatching by using a brooder (Ziss tumbler ZET-65, KOREA). The water temperature was maintained between $20^{\circ} \mathrm{C}-22^{\circ} \mathrm{C}$ (average $21^{\circ} \mathrm{C}$ ). The egg size was measured up to $0.01 \mathrm{~mm}$ by using a profile projector and egg development was observed by photographing the eggs with a stereoscopic microscope and sketching the chracteristics found during the development. The larvae were bred in a glass rectangular tank $(45 \times 45 \times 30 \mathrm{~cm})$ and using a sponge filter for recirculating system. From 3 days after hatching until 11 days after hatching, 5 to 10 individuals of Artemia sp. nauplius per $\mathrm{mL}$ were supplied and, later, frozen blood worms were provided. To observe morphological development of the larvae, we collected 5 individuals every day from hatching until 25 days after hatching and 5 individuals every 5 days from the juvenile period until 60 days after hatching to anes the size them using anesthetic (MS222, Tricaine methane sulfonate: Sandoz) and observe and photograph their morphological development with a stereoscopic microscope. The size of the larvae was measured up to $0.01 \mathrm{~mm}$ by using a profile projector. 


\section{RESULTS}

\section{Characteristics of eggs and spawning amount}

C. herzi lays round demersal eggs with many oil droplets with adhesive surface. The color of yolk changed from yellow and yellow green immediately after spawning to dark green as time passed by. The eggs were about $2.75-3.39 \mathrm{~mm}$ (average $2.95 \pm 0.25, \mathrm{n}=100$ ) in size and the number of oil droplets was between 18 and 20, and the size $0.001-0.009 \mathrm{~mm}$ (average $0.005 \pm 0.005, \mathrm{n}=100$ ). On average, one female individual spawned 541 to 861 eggs (average 701) at once and, on each PVC pipe, 3 to 4 females per each male spawned in order.

\section{Egg development process}

Eggs of $C$. herzi formed the egg membrane from 30 minutes after fertilization when they began to absorb water; one hour after fertilization, the egg yolk and membrane were completely separated. One and a half hours after fertilization, 1 embryo disc was developed on the animal pole (Fig. 1A), and, at 2 hours after fertilization, cell began to divide, resulting in two blastomeres of the same size and, therefore, 2 cells (Fig. 1B). At 3 hours after fertilization, four blastomeres were divided 4 cells (Fig. 1C); at 4 hours after fertilization, it reached the 8 cells (Fig. 1D); and, at 5 hours after fertilization, the 16 cells (Fig. 1E). At 8 hours after fertilization, the number of blastomeres gradually increased, reaching the 32 cell phase (Fig. $1 \mathrm{~F}$ ), and, at 11 hours after fertilization, 64 cell phrase (Fig. 1G). At 16 hours after fertilization, the size of blastomeres decreased, reaching the morula stage, while the number of blastomeres increased to a degree it could not be counted

A

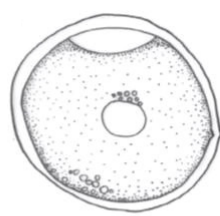

$\mathbf{E}$

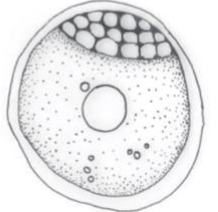

I

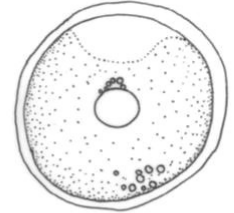

M

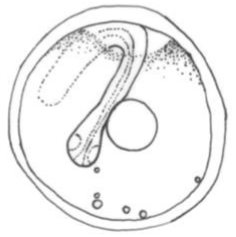

B

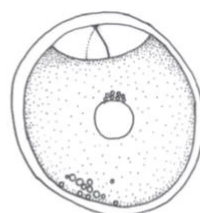

$\mathbf{F}$

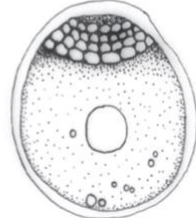

J

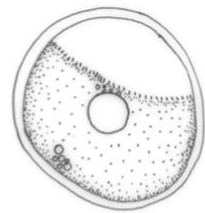

$\mathbf{N}$

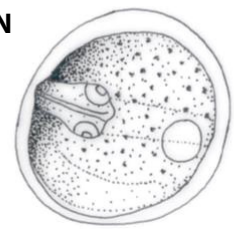

C

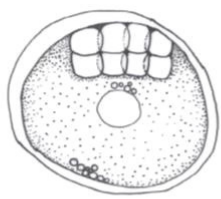

G

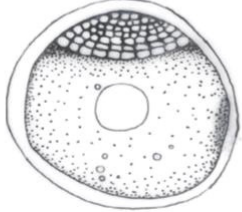

$\mathbf{K}$

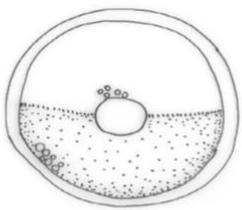

$\mathbf{0}$

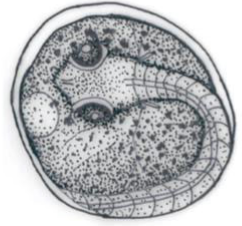

D

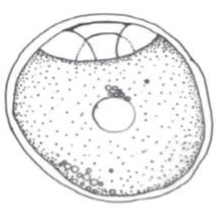

H

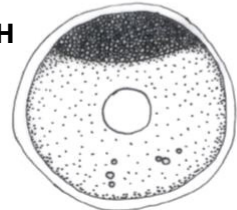

$\mathbf{L}$
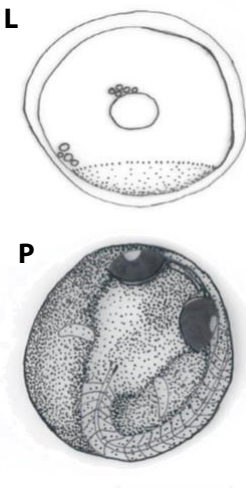

Fig. 1. Egg development of Coreoperca herzi in Han River, Korea. A, Blastodisc; B, 2 cells; C, 4 cells; D, 8 cells; E, 16 cells; F, 32 cells; G, 64 cells; H, Morula stage; I, Blastrula stage; J, Early gastrula stage 1/3; $\mathrm{K}$, Middle gastrula stage 2/3; L, Late gastrula stage 3/3; M, Embryonic stage; N, Development of tail; O, Development of primordial fin; P, Embryo just before hatching. Scale bar, $1.00 \mathrm{~mm}$. 
(Fig. 1H). At 22 hours after fertilization, it reached the blastula stage (Fig. 1I); at 49 hours after fertilization, the germ disc covered one-thirds of the yolk, indicating the early gastrula stage (Fig. 1J) and, at 54 hours after fertilization, it covered two-thirds of it, indicating mid-gastrula stage (Fig. 1K). At 61 hours after fertilization, the germ disc covered almost all of the yolk, indicating the late gastrula stage (Fig. 1L), and at 64 hours after fertilization, the gastrula stage came to an end, indicating blastoderm covered. At 68 hours after fertilization, the embryo began to form (Fig. 1M). At 75 hours after fertilization, the tail of the embryo started to be formed (Fig. $1 \mathrm{~N}$ ); at 81 hours after fertilization, the Kuffer's vesicle formed in a round shape at the end of the tail and disappeared at 83 hours after fertilization. At 86 hours after fertilization, branch-shaped melanophores began to form in the yolk and embryo, and at 89 hours after fertilization, the lenses in the head began division and, at the 109 hours point, embryo began to move actively. At 135 hours after fertilization, melanophores began to settle in the eyes and, at 153 hours after fertilization, active heartbeat and blood circulation around the yolk and embryo base were observed. At 179 hours after fertilization, a fin was formed as a membrane on the embryo (Fig. 1O). At 207 hours after fertilization, the tail of the embryo grew up until the top of the head, and the eyes showed clear pupils. At 235 hours after fertilization, a membrane chest fin was developed (Fig. 1P); At 259 hours after fertilization, the tail broke out of the egg membrane and hatching began. At 283 hours after fertilization, all individuals finished hatching.

\section{Larvae and juveniles development}

Immediately after hatching, the larvae were from $7.73 \mathrm{~mm}$ to $7.93 \mathrm{~mm}$ (average $7.81 \pm 0.10, \mathrm{n}=5$ ) in the total length, began swimming, and, although the mouth and anus were open, did not eat the feed. Yolk was observed in the abdomen, with one oil droplets and a membrane fin on the chest. Melanophores were formed in a branch shape on the center and back of the head as well as on the top of the yolk. Fins began to divide on different parts of the body. On the dorsal fin, 13 interneural spine were formed and, on the anal fin, 10 interhemal spine on the caudal fin, $16(16=8+8)$ fin rays were developed (Fig. 2; D-0).

3 days after hatching, the total length of the larvae ranged from $8.98 \mathrm{~mm}$ to $9.53 \mathrm{~mm}$ (average $9.17 \pm 0.30, n=5$ ); the yolk and one oil droplets were mostly absorbed, and the lower jaw grew longer than the upper jaw, allowing the larvae to actively consume the feed. The shape of melanophores settled on the center and back of the head and on top of the yolk changed from branches to spots, and new melanophores settled on the lid of the gills. The dorsal, anal and caudal fins were separated completely. As for the number of fin rays, 14 fin rays were observed on the dorsal fin and 12 fin rays on the anal fin (Fig. 2; D-3).

5 days after hatching, the postlarvae were from $10.3 \mathrm{~mm}$ to $11.6 \mathrm{~mm}$ (average $10.8 \pm 0.66$, $\mathrm{n}=5$ ) in the total length. The melanophores that were settled on the entire abdomen decreased in number, extending from the upper part of the air bladder to the back, while the area covered by melanophores on the center of the head increased. The melanophores settled on the lid of the gills extended as a straight line to the end of the mouth, and new melanophores were formed on the caudal peduncle and top of the back. As for the number of fin rays on the fins, those on the 12 dorsal fin rays increased and 14 spiny soft fin rays and, on the 2 anal fin rays and 10 soft fin rays were developed. The caudal fin increased to $17(9+8=17)$ (Fig. 2; D-5).

11 days after hatching, the total length of the advanced juveniles were from $14.5 \mathrm{~mm}$ to 14.9 $\mathrm{mm}$ (average 14.6 $\pm 0.20, \mathrm{n}=5$ ). The melanophores spread, connecting the overall head area and the ends of the mouth, and new melanophores were settled under the eyes. The melanophores settled on the caudal peduncle and on top of the back spread to the rest of the body. The number of dorsal 


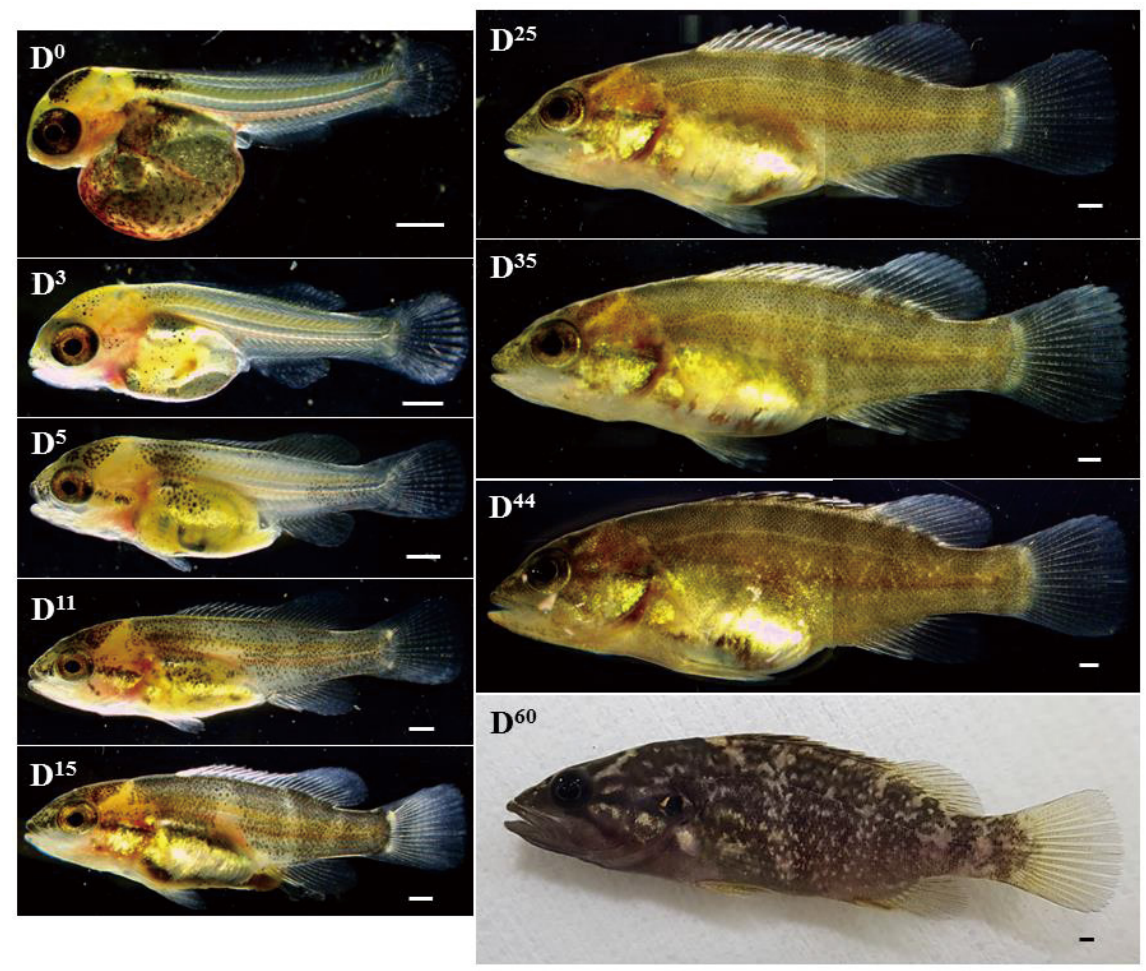

Fig. 2. Morphological development of the larvae and juveniles of Coreoperca herzi in Han River, Korea. Scale bars, $1.00 \mathrm{~mm}$.

fin rays increased to 13 fin rays and 14 spiny soft fin rays, and two round white spots were formed on the top and bottom of the starting point of the caudal fin (Fig. 2; D-11).

15 days after hatching, the advanced juveniles were from $15.0 \mathrm{~mm}$ to $16.3 \mathrm{~mm}$ (average $15.6 \pm 0.65, n=5)$ in size. The melanophores settled on the entire body transformed into four horizontal stripes including that on the head. The white spots on the top and bottom of the caudal fin gradually expanded and were connected with each other (Fig. 2; D-15).

25 days after hatching, the advanced juveniles were from $19.8 \mathrm{~mm}$ to $23.0 \mathrm{~mm}$ (average $21.6 \pm 1.63, n=5$ ) in size, and the melanophores were developed into six to seven horizontal stripes. On the center of the dorsal and anal fins, a line of melanophores was formed. The number of anal fin rays increased to 3 fin rays and 10 spiny fin rays, and the $19(10+9)$ caudal fins. The numbers of fin rays on all fins became whole numbers, indicating the juvenile period (Fig. 2; D-25).

35 days after hatching, the juveniles were from $21.0 \mathrm{~mm}$ to $26.5 \mathrm{~mm}$ (average $23.7 \pm 2.75, \mathrm{n}=5$ ) in the total length. At this time, a white spot began to form on the abdomen (Fig. 2; D-35); and, on day 44, the total length were from $27.6 \mathrm{~mm}$ to $29.1 \mathrm{~mm}$ (average $28.3 \pm 0.75, \mathrm{n}=5$ ), with the white spots on the abdomen spreading along the center of the body to the starting point of the caudal fin (Fig. 2; D-44).

60 days after hatching, the juveniles were from $35.0 \mathrm{~mm}$ to $37.4 \mathrm{~mm}$ (average $35.9 \pm 1.30$, $\mathrm{n}=5$ ) in total length. The white spots spread to the rest of the body, rending the same pattern as that on the body of their broodstock fish (Fig. 2; D-60).

\section{DISCUSSION}

While breeding $C$. herzi in the environment described in this study, we found that multiple 
females spawned in a male spawning ground, on average 541-861 eggs (average 701) at once. Han River $C$. herzi collected and observed fertilized eggs directly from the spawning broodstock in the rear tank. The fertilized eggs of $C$. herzi inhabiting Han River were $2.75 \mathrm{~mm}$ to $3.39 \mathrm{~mm}$ in size and those of $C$. herzi living in Gyeongho River and Deokcheon River (Han et al., 1998) $2.60 \mathrm{~mm}$ to $3.04 \mathrm{~mm}$ larger than C. kawamebari (Han et al., 2000), which belong to the same genus, 2.21-2.65 mm; Japan-native C. kawamebari (Imai \& Nakahara, 1957) 2.20-2.40 mm; and Siniperca scherzeri (Lee et al., 1997) 1.72-2.05 mm.

Hatching timing (ranging 259-283 hours at $21^{\circ} \mathrm{C}$ ) for the Han River population was slightly shorter than the previous study that is based upon the conspecific populations from the Nakdong River (ranging 380-390 hours at $19^{\circ} \mathrm{C}$ ) (Han et al., 1998). For hatching, C. kawamebari (Han et al., 2000) took 194 hours and 23 minutes at $18.2^{\circ} \mathrm{C}-22.0^{\circ} \mathrm{C}$; Japanese C. kawamebari (Imai \& Nakahara, 1957) $195-231$ hours at $20^{\circ} \mathrm{C}-23^{\circ} \mathrm{C}$; and, S. scherzeri (Lee et al., 1997) 130-150 hours at $20^{\circ} \mathrm{C}-25^{\circ} \mathrm{C}$, which are shorter than the hatching time of Han River C. herzi (Fig. 3). The hatching periods varied between different species and were generally shorter at higher water temperature.

The size of fertilized eggs is directly proportional to the size of hatching juvenile; in other words, the species whose fertilized eggs are relatively small were also small as hatching juvenile. This is also directly related to the hatching time or the number of eggs brooding and, therefore, to the early breeding strategy of the species who belong to the same genus of similar ecological status (Lee et al., 2013). Hatching juvenile of the Han River group were between $7.73 \mathrm{~mm}$ and $7.93 \mathrm{~mm}$ in the total length and those of the Gyeongho and Deokcheon River groups (Han et al., 1998) between 6.45-7.34 mm. The Han River group spawned relatively large eggs and, therefore, their hatching juvenile were also larger than the other groups observed in this study. Of the same genus, $C$. kawamebari (Han et al., 2000) ranged between 5.09 and $5.68 \mathrm{~mm}$ in size, therefore, larger than the Japanese C. kawamebari (Imai \& Nakahara, 1957), which are 5.06 to $5.08 \mathrm{~mm}$ and S. scherzeri (Lee et al., 1997) 5.50-7.10 mm. Moving to the juvenile stage, on the 25 days after hatching, they were $19.8 \mathrm{~mm}$ to $23.0 \mathrm{~mm}$ in the total length; in comparison, the individuals collected from Gyeongho and Deokcheon Rivers (Han et al., 1998) were $16.9 \mathrm{~mm}$ to $19.8 \mathrm{~mm}$ on the 30 days. The average total length of C. kawamebari (Han et al., 2000), which belongs to the same genus, was $13.5 \mathrm{~mm}$

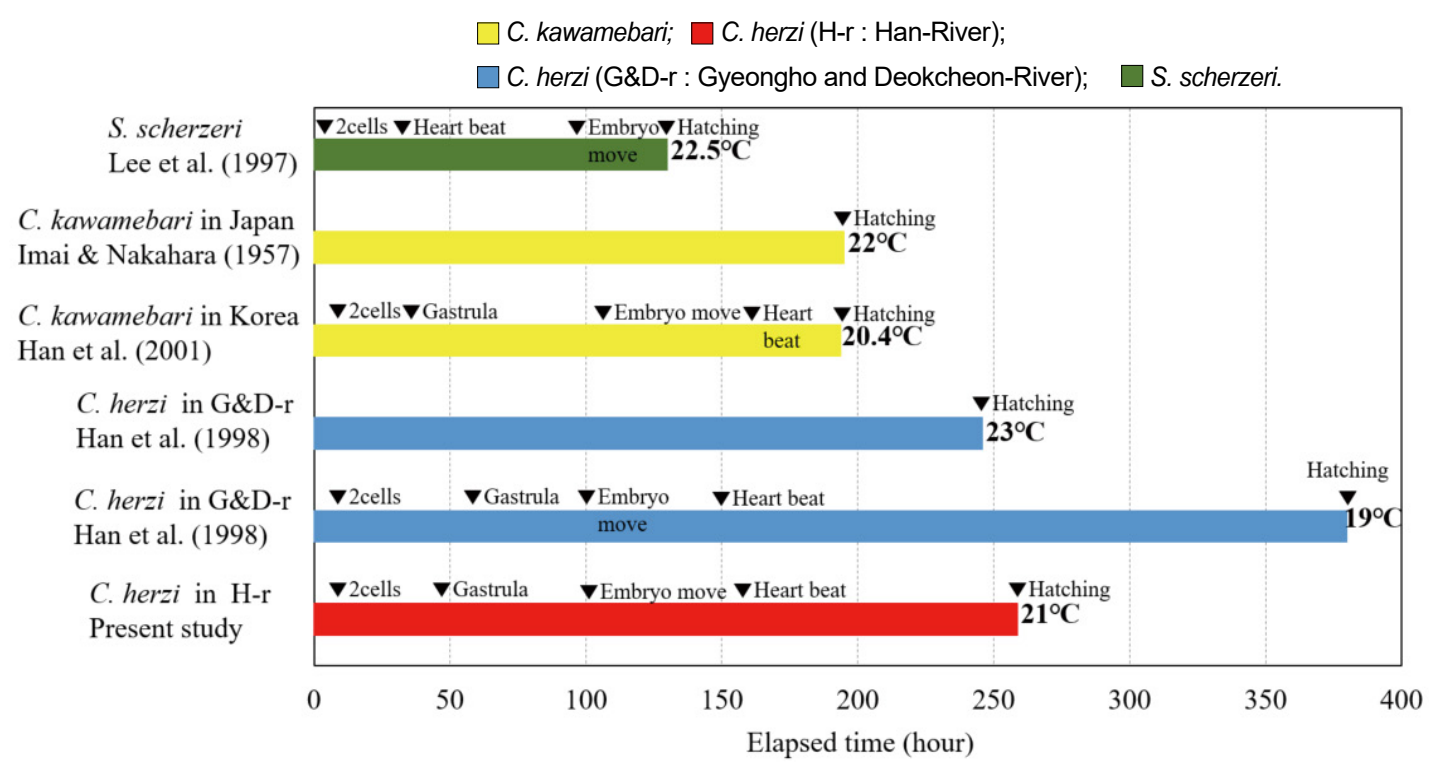

Fig. 3. Comparison of elapsed time after fertilization of Centropomidae fishes by water temperatures. 
on the 32 days after hatching; that of Japanese C. kawamebari (Imai \& Nakahara, 1957) $12.2 \mathrm{~mm}$ on the 32nd day; and the total length of $S$. scherzeri (Lee et al., 1997) between $13.6 \mathrm{~mm}$ and 15.6 $\mathrm{mm}$ on the 20 days. In short, the juvenile stage of the Han River as to other speices while the total length was larger. Although the time of transition is believed to vary according to the feed, water temperature, and other environmental factors, the total length seems to depend on the species.

In this study, six horizontal stripes on the side and white spot on the abdomen were observed on the 35 days after hatching, when the total length was between $21.0 \mathrm{~mm}$ and $26.5 \mathrm{~mm}$; and, on the 60 days, when the total length was between $35.0 \mathrm{~mm}$ and $37.4 \mathrm{~mm}, 7$ to 8 horizontal stripes and random triangle or rhombus white spots were formed on the side. By contrast, in individuals collected from Gyeongho and Deokcheon Rivers (Han et al., 1998), on the 30 days after hatching when the total length was between $16.9 \mathrm{~mm}$ and $19.8 \mathrm{~mm}$, melanophores spread over the entire body and pigmentation. On the 40 days after hatching, when the total length was between 22.1 $\mathrm{mm}$ and $22.5 \mathrm{~mm}, 6$ to 8 horizontal stripes were formed and, on the 120 days when the total length was $36.0 \mathrm{~mm}$ to $40.0 \mathrm{~mm}, 7$ to 8 dark brown horizontal stripes were formed, presenting morphological differences from the Han River group (Fig. 4). As for the numbers of fin rays, there were 13 dorsal fin rays, 14 spiny soft rays, 3 anal fin rays, 10 spiny soft rays, and 10+9=19 caudal fins. In the individuals from Gyeongho and Deokcheon Rivers (Han et al., 1998), 13 dorsal fin rays, 13 spiny soft rays, 3 anal fin rays, 8 spiny soft rays, and 16 caudal fins were observed (Table 1).

Overall, we found an evidence that a difference at early life stage between Nakdong and Han River in terms morphological development. The Han River population can be characterized the following features. First, the egg and larvae from the Han River population not only developed faster, but also grew bigger than the Nakdong River population. Second, the white spots upon their body appeared in Han River population since the 15 days after hatching stage. This might be used as one of the characters to determine a taxonomic status of the Han River population since it is consistently present upon the body in adult stage. Kim (2005) reported difference in the numbers of pectoral, anal, caudal fin rays, taxonomic character, between individuals inhabiting Han River and Geum River, and those living in Yeongsan River, Seomjin River, and Nakdong River. This study also found that the numbers of dorsal, anal, caudal fin rays varied between individuals in Han River and

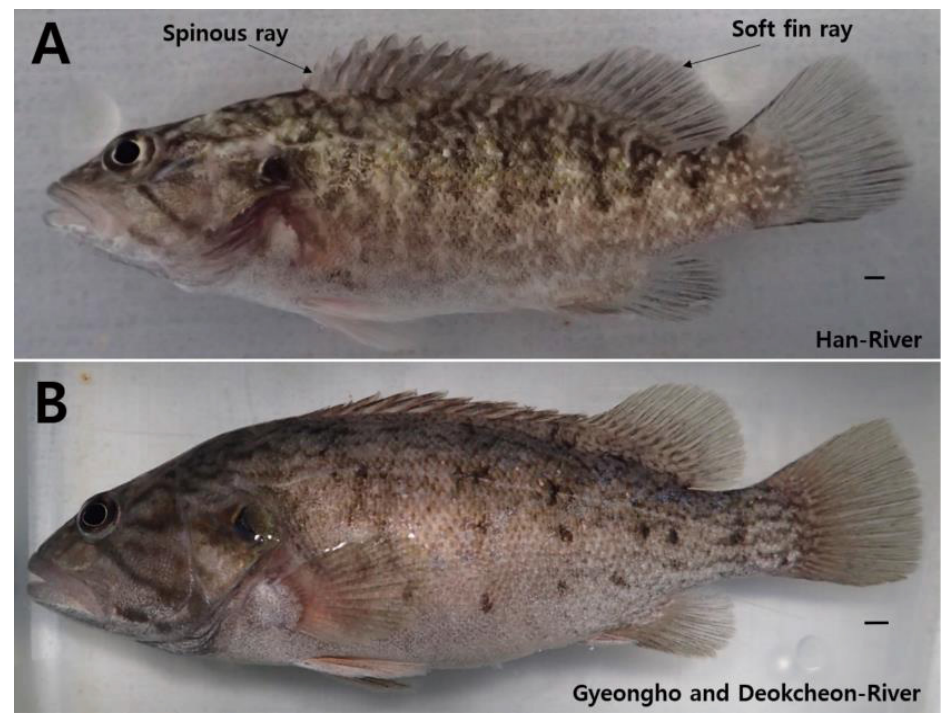

Fig. 4. Morpological of lateral view that Coreoperca herzi. (A) Han River (60 days after hatching in $35.9 \mathrm{~mm}$, $21^{\circ} \mathrm{C}$ ) and (B) Gyeongho and Deokcheon River (60 days after hatching in $29.3 \mathrm{~mm}, 19^{\circ} \mathrm{C}$ ). Scale bars, $1.00 \mathrm{~mm}$ 
Table 1. Comparison of fin ray numbers development in larva and juvenile Coreoperca herzi inrelation to stream

\begin{tabular}{|c|c|c|c|c|c|c|c|c|c|}
\hline Species & Fin Days & 0 & 3 & $5-6$ & $10-11$ & $15-16$ & 25 & 30 & Authors \\
\hline \multirow{3}{*}{$\begin{array}{l}\text { Coreoperca herzi } \\
\text { (Han River) }\end{array}$} & Dorsal fin & & 14 & $X \amalg 14$ & $\mathrm{X} \mathbb{\mathrm { II }} 14$ & & & & \multirow{3}{*}{ Present study } \\
\hline & Anal fin & & 12 & ㅍ10 & & & III10 & & \\
\hline & Caudal fin & 16 & & 17 & & & 19 & & \\
\hline \multirow{2}{*}{$\begin{array}{c}\text { C. herzi } \\
\text { (Gyeongho and } \\
\text { Deokcheon-River) }\end{array}$} & Dorsal fin & & $9-11$ & IX11-12 & X II11-12 & X III11-12 & & $\mathrm{X} \mathbb{\mathrm { II }} 13$ & \multirow[b]{2}{*}{ Han et al. (1998) } \\
\hline & Anal fin & & $7-8$ & 표 & 五8 & & & & \\
\hline
\end{tabular}

Roman numeral, spinous ray; Arabic numeral, soft fin ray.

Nakdong River during the early life stage. The findings confirm that the morphological differences between the two groups occur from the larva and juvenile period and further research will be needed to investigate the possibility of mutation as a result of long-term geographical separation between individuals inhabiting Han River and those in Nakdong River from the molecular genetics viewpoint.

\section{REFERENCES}

Han KH, Park JT, Jung GH, Lee WK, Lee JY, Bang IC (1998) Spawning behavior and early life history of Korean aucha perch, Coreoperca herzi Herzenstein.J Aquacult 11:49-58.

Han KH, Park JT, Kim BM, Oh SH, Lee SH, Jin DS (2000) Spawning behavior and early life history of aucha perch, Coreoperca kawamebari from Korea. Korean J Ichthyol 12:129-136.

Imai S, Nakahara K (1957) The life history of Coreoperca kawamebari (T. \& S.). In: Suehiro Y, Ohshima Y, Hiyama Y (eds) Suisangaku Shusei. University of Tokyo Press, Tokyo, Japan, pp 591-601.

Jeon HB (2005) Freshwater fishes in mankyeong-river. Available from: http://fishes.tistory. com/273. Accessed at September 28, 2019.

Jeon SR (1980) Studies on the distribution of freshwater fished from Korea. Ph.D. Dissertation, Chung-Ang University, Seoul, Korea.p 91.

Kim IS (1997) Illustarated Encyclopedia of Fauna \& Flora of Korea. Vol. 37, Freshwater Fishes. Ministry of Education, Seoul, Korea, p 629.

Kim IS, Choi Y, Lee CL, Lee YJ, Kim BJ, Kim JH (2005) Illustrated Book of Korean Fishes. Kyohak, Seoul, Korea, pp 270-271.

Kim MJ (2005) Origin and biogeography of the Korean perch (Coreoperca herzi) and its relatives based on phylogenetic approach with cytochrome b DNA sequences. M.S. Thesis, Cheju University, Jeju, Korea, p 40.

Lee WO, Lee JY, Son SJ, Choi NJ (1997) Early life history and reproductive ecology of mandarin fish, Siniperca scherzeri (Pisces, Centropomidae) in Soyang Lake. Korean J Ichthyol 9:99-107.

Lee WO, Kim KH, Back JM, Song MY (2013) Egg development and early life history of Zacco koreanus. Korean J Ichthyol 25:200-207.

Park JY, Kim SH (2010) Liobagrus somjinensis, a new species of torrent catfish (Siluriformes: Amblycipitidae) from Korea. Ichthyol Explor Freshwaters 21:345-352.

Song HY, Bang IC (2015) Coreoleuciscus aeruginos (Teleostei: Cypriniformes: Cyprinidae), a new species from the Seomjin and Nakdong rivers, Korea. Zootaxa 3931:140-150.

Song HB, Choi SS (2000) Reproductive ecology and early life history of paradise fish, Macropodus chinensis (Pisces; Belontidae) in aquarium. Korean J Limnol 33:282-294. 